\title{
PROJEV PRODĚKANA PRÁVNICKÉ FAKULTY UNIVERZITY KARLOVY PROFESORA MICHALA TOMÁŠKA V RAKOUSKÉM KULTURNÍM FÓRU U PŘÍLEŽITOSTI ZAHÁJENÍ KONFERENCE HANS KELSEN - INSPIRUJÍCÍ OSOBNOST PRO PRÁVNÍ VĚDU, FILOZOFII, POLITIKU A MEZINÁRODNÍ VZTAHY DNE 8. ŘÍJNA 2015
}

Vaše Excelence pane velvyslanče Rakouské republiky, milý pane prezidente Schambecku, vážené kolegyně, vážení kolegové, dámy a pánové.

Téma přednášky Hans Kelsen na prahu 21. století je pro mě neodmyslitelně spojeno se jménem předního rakouského ústavního vědce profesora Herberta Schambecka, jehož přednášku jsme právě vyslechli. Je to právě profesor Schambeck, který Kelsenovy myšlenky uvedl do našeho století ve svých dílech, publikovaných nejen v Rakousku, ale $\mathrm{i}$ jinde v Evropě a ve světě. $Z$ mého pohledu profesora evropského práva považuji za významné, jak Kelsenův myšlenkový odkaz dokázal promítnout do dnešní evropské konstrukce.

Profesor Herbert Schambeck vyjadřuje ve své knize „Beiträge zum Verfassungs und Europarecht" myšlenku, že Rakousko, na rozdíl od jiných zemí, nemá pevné datum vzniku své státnosti. Za vytvoření rakouského státu označuje svazek německy (a dlouho i česky) mluvících zemí. Bývalý rakouský spolkový kancléř Dr. Wolfgang Schüssel vzpomíná, že nový rakouský stát byl i po první světové válce vytvořen spojením německy mluvících spolkových zemí a obdobně pojalo Rakousko své přistoupení k Evropské unii.

Toto rakouské pojetí EU jako entity vytvořené spojením evropských států dává částečnou odpověd' na otázku, co vlastně je Evropská unie. Německý Spolkový ústavní soud kdysi řekl, že EU není spolkový stát „Bundesstaat“, nýbrž společenství států „Staatenverbund“. Nejde ovšem jen o pojmy. Rakouský pohled na EU, popsaný profesorem Schambeckem, implikuje silné sebevědomí jednotlivých zemí. A profesor Schambeck ví, o čem mluví. Jako prezident Spolkové rady prosadil podstatné posílení pravomocí spolkových zemí na úkor vídeňských federálních prerogativů.

Rakouské sebevědomí v Evropě má přirozeně vlastní význam. Je opodstatněné a konsekventně se drží evropských hodnot. Také my v Česku jako středně veliké evropské zemi musíme stejným způsobem patřit do Evropy. Je na čase méně naříkat na evropskou integraci a na evropské struktury, ale více rozvíjet české myšlenky v Evropě, aby, stejně jako myšlenky rakouské, mohly integrační procesy obohatit.

Dvacáté století, jako žádné století předtím, ukázalo, jak křehké jsou hranice zachování naší civilizace. Zkušenosti z jejího ohrožení v první polovině minulého století vedly 
po druhé světové válce k založení Organizace spojených národů, Všeobecné deklaraci práv a svobod přes Smlouvy o EHS, EU až k Lisabonské smlouvě. Profesor Herbert Schambeck ve svém díle napsal: „Cesta ke státoprávnímu soužití vedla prostřednictvím EU ke spolku států, které se rozhodly sdílet hospodářské a měnové společenství, jakož i společenství právní a hodnotové. Státy jako Rakousko nebo Česko, ležící v srdci Evropy, mohou stavět mosty a otevírat okna, jakož i přispívat $\mathrm{k}$ uchování míru v Evropě i v celém mezinárodním společenství." Konec citátu.

Česko a Rakousko mají společnou minulost a po desetiletích rozdělení železnou oponou se setkaly na cestě do společné budoucnosti v Evropské unii. Letos si Rakousko připomíná dvacáté výročí vstupu do Evropské unie. Má tedy o deset let delší zkušenosti člena rodiny evropských států. Pro naši právní vědu, zejména pro nauku evropského práva, patří proto rakouské zkušenosti $\mathrm{k}$ těm $\mathrm{z}$ nejcennějších; jako zkušenosti malého středního státu se společnými dějinami a srovnatelnou právní mentalitou. Proto se rádi přidržujeme odkazu takových vědeckých osobností jako Hans Kelsen, který proslavil rakouskou právní vědu ve světě, nebo Antonín rytî̌ Randa, který proslavil v Rakousku tehdy ještě mladou právní vědu českou.

Děkuji vám za pozornost. 